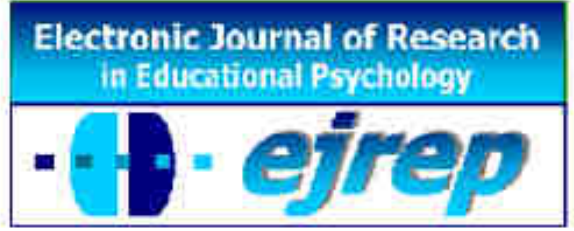

\title{
Examining the psychometric properties of the Emotional Regulation Checklist in 4- and 5-year-old preschoolers
}

\section{Şahin Danişman ${ }^{1}$, Esra Dereli İman ${ }^{2} a^{*}$ Zeynep Akın Demircan $^{1}$ \& Dilara Yaya ${ }^{2}$}

${ }^{1}$ Department of Educational Sciences, Eskişehir Osmangazi University, Eskişehir

${ }^{2}$ Department of Primary Education, Eskişehir Osmangazi University, Eskişehir

\section{Turkey}

*Corresponding Author: Esra Dereli-İman. Eskişehir Osmangazi University, Faculty of Education, Department of Preschool Education, Eskişehir-Turkey.e-mail: derelie@ ogu.edu.tr

(C) Education \& Psychology I+D+i and Ilustre Colegio Oficial de la Psicología de Andalucía Oriental (Spain) 


\section{Abstract}

Introduction. Emotinal Regulation Checklist is frequently used to determine emotional developments of children by teacher and parents of children. The purpose of this study was to examining the Psychomectric Properties of Emotinal Regulation Check List for 4-5 years age in preshool children.

Method. The sample of the research was composed of 600 preschool children, who are all 45 years old, from 13 different public schools in Eskişehir (Turkey). This study is a quantitative and relational study. The data were collected by Emotinal Regulation Check List and PreSchool Social Competence and Behavior Evaluation Inventory-Teacher Form.

Results. The factor structure of the scale was tested through confirmatory factor analysis (CFA) and the results indicate that the original factor model did not fit the data. Exploratory factor analysis (EFA) results differed from the original study in that item twelve took place in the first factor. CFA results revealed an acceptable model fit and suggested that two factor model was confirmed with the second dataset. Cronbach Alpha internal consistency coefficients were acceptable for subscales. Positive and negative medium level meaningful relations were found between emotion regulation checklist sub-factors and social compotence and behavior the sub-factors.

Discussion and Conclusion. As a result of, it can be concluded that scale is a reliable and valid measurement tool for measure the emotion regulation behaviors of 4-5-year-old children. The findings of this study indicate the need to Education programmes developed to increase emotinal regulation of children, and their efficiency evaluated via this assessment instruments.

Keywords: preschool education, emotional regulation, social compotence, social behavior. 


\section{Resumen}

Introducción. Las listas de comprobación regulación de las emociones para determinar el desarrollo del sentimiento de los niños, se utiliza con frecuencia por los niños, profesores y padres. El objetivo de este studio estuvo centrado en niños de edad preescolar pertenecientes a una de lista de verificación de la regulación emocional, para evaluar las propiedades psicométricas.

Método. La muestra del estudio consiste en, en el grupo de 4-5 años de edad, Turquía / Participaron trece escuelas diferentes antes de asistir a instituciones educativas, con 600 niños. Esta estudio investigación relacional es cuantitativa. Los datos de la investigación fueron recolectados a través de un "Listado de Regulación de Emocionesl “, un "Inventario de habilidades socias" y una "Escala de comportamiento, calificado por el professor".

Resultados. Modelos a escala de la idoneidad de la estructura factorial y la validez de constructo se analizó mediante análisis factorial confirmatorio (CFA); sin embargo, se encontró que la escala para estar en conformidad con el modelo original del factor de estructura. En el análisis factorial exploratorio, en una escala diferente de la estructura factorial original del segundo elemento que se encuentra en el primer factor. CFA resultados revelaron que un modelo aceptable apropiado y se confirmaron mediante el modelo de dos factores el segundo conjunto de datos. Se encontró coeficiente de consistencia interna Cronbach Alpha aceptable. Las relaciones significativas nivel medio positivas y negativas se encontraron entre la lista de control de regulación emocional subfactores y la competencia social y el comportamiento de los subfactores.

Discusión y Conclusión. El estudio concluyó que la escala es una herramienta de medición válido y fiable para medir el comportamiento de regulación de las emociones de los niños de 4-5 años de edad. Los resultados del estudio mostraron que se necesita regulación de las emociones para mejorar de sus hijos en el desarrollo de programas educativos y la eficacia de los programas de formación pueden ser evaluados por el instrumento de medición.

Palabras Clave: educación preescolar, regulación de las emociones, competencia social, 


\section{Introduction}

Pre-school age is the period in which the development of children is the most rapid and the most critical. Pre-school period is significant in emotional development similar to other areas of development. Piaget (1965) identified the pre-school period as the age of curiosity. In this period, the child learns about the surrounding complex social world through active experiences. The foundation of emotional characteristics is laid in the pre-school period, and they affect the achievement of more complex social skills in the future. Children proceed to group socialization and interactive play with their peers from egocentric thoughts and behaviors during the pre-school period. Children transform from caretaker/parent relationship in customary domestic environment into a group socialization and interactive peer relationship in the school environment. During this change of interactions, it is expected from the child to learn social skills, to behave pro-social, to initiate friendships and play with her or his peers (Bronson, 2000; Davies, 2004).

One of the developmental tasks that affect the acquirement of these characteristics is the achievement of the ability to manage their emotions while conducting their relations with individuals outside their family by the children. Management of emotions is related to the emotional development of the child. Emotional development is the knowledge of the individual about the connection between her or his feelings and emotions, being in peace and in cohesion with her or his own self and the environment, and being able to control her or his emotions (Saarni, 2001). Emotions are directive, conductive, and sometimes preventive of our actions. Saarni (1999, pp. 344) defined emotion as "the attempts or preparation to establish, maintain or change relationships between the environment and the individual in issues significant for the individual." Emotions are strong determinants of our actions in social situations; emotions conduct even determine social interactions and relationships (Denham, 2007; Saarni, 1999). Emotional competence is the individual's ability to regulate one's emotions to reach her or his goals. For pre-school children, emotional competence includes the abilities to express their emotions, to understand emotions, and to regulate emotions (Colwell \& Hart, 2006; Eggum et al., 2011). Skills of understanding and regulating emotions are significant behavioral elements in individuals initiating and maintaining positive interactions with others (Vural and Gürşimşek, 2009). Early childhood is a critical period for the development of chil- 
dren's understanding of emotions, emotion regulation skills, value systems and selfconfidence social competence (Berk, 2000; Blair et.al, 2004; Carlson ve Wang, 2007)

Emotion regulation refers to "the processes by which individuals influence which emotions they have, when they have them, and how they experience and express these emotions" (Gross 1998, pp. 275). Emotion regulation is defined conceptually as the individual's ability to organize his or her emotional stimulations to achieve a compatible relationship with the environment (Shields \& Cicchetti, 1997; Thompson, 1994). Emotion regulation is not only the ability to cope with negative emotions, but it is also the ability to maintain positive emotions (Denham, 1998; Hyson, 2004). Emotion regulation includes internal and external processes that does not only consist of reducing the emotion itself, the way it is perceived, its intensity and frequency, but to create and sustain the emotional response. Internal emotion regulation processes contain self-regulation of the individual's emotions, while the external processes entail someone else regulating the individual's emotions (Thompson,1994). Emotion regulation is critical both in initiating, motivating, and organizing adaptive behavior, and in preventing stressful levels of negative emotions and maladaptive behavior (Cicchetti, Ackerman, and Izard, 1995). Emotion regulation is important in the case of positive and negative emotions, and it becomes more crucial as the intensity of a given emotion increases (Sobanski et al., 2010). Effective emotion regulation has been linked with a number of positive emotional, social, and cognitive outcomes. Children that has the skill to regulate emotions could manage their emotions under every situation, reducing the possibility of exhibiting externalized and destructive behavior, and succeed in social and interpersonal relationships, and experience an increase in academic achievements (Howse et al., 2003; Luby, 2005). Variability/negativity is about children responding rapidly to emerging emotional stimulants and experiencing difficulties in recovering from negative emotional reactions (Dunsmore, Booker \& Ollendick, 2011). Variability/negativity in emotion regulation is directly related to internal and external behavioral problems, failure in social competencies, and destructive behavior disorders (Denham, 1998; Eisenberg et al., 1995; Kim \& Deater-Deckard, 2011; Shields \& Cicchetti, 1998; Shields, Cicchetti \&Ryan, 1994).

Postnatal development of emotion regulation begins in infancy and continues through toddlerhood and childhood with the support of parents, teachers, and other caregivers Trevarthen \& Aitken, 2001). Emotion regulation at all ages is negatively correlated with internalizing symptoms, and successful regulators are less likely to show impulsive tendencies (Kim- 
Spoon et al., 21013; Spinrad et al., 2006). As children age, they become more skillful in the area of emotion regulation and are less emotionally reactive (Morris et al., 2010; Spinrad et al., 2006). Pre-school children (aged 3 - 5) could increasingly determine their emotional experiences and recognize possible precursors and outcomes of emotional responses. Furthermore, these children could identify the situational determinants of emotional responses, read the emotional clues, and become competent in taking the emotional perspective of someone else. These skills empower the children in regulation of their emotional expressions and behavior, recognition, prediction, and reflection of different emotional experiences for conformity. For pre-school children to develop their emotion regulation skills, their educational environment should provide them opportunities of practicing these skills (Dickstein et. al., 2001; Dunn \& Brown, 1993; Garner, Jones \& Miner, 1994; Russell, 1990; Saarni, 1999). Lack of emotional competencies results in rejection of the children by their peers, solitude, social skill deficiencies, aggressiveness, antisocial behavior, and behavioral disorders, resulting in an increase in these problems in the future periods of development (Garner, 2010; Raikes \& Thompson, 2006; Raver \& Knitzer, 2002; Shackman et al., 2010). Identification of emotional competencies in pre-school children is significant for taking early precautions and implementation of preventive educational programs for affected individuals (Raikes \& Thompson, 2006).

\section{The aims}

Purpose the main purpose of study was to adapt the Emotional Regulation Checklist for 4-5 year old children. The secondary purpose of the study was to investigate the whether relation between emotional regulation subdimensions and social compotence- behaviour subdimensions of children.

\section{Method}

\section{Participants}

The universe of the study consists of children at the age group of 4-5 who attend pre-schools in Eskişehir/ Turkey city center. Before the scales were conducted, permission was obtained from Ministry of National Education, and teachers and parents of the children. The sample of the research was composed of 631 preschool children, who are all 4-5 years old, from 13 different public schools in Eskişehir, Turkey. Thirty one participants' scales were removed be- 
fore the analyses, since the items in these scales were not scored appropriately. Hence, the dataset contained the data obtained about 600 preschool children Validity and reliability studies of the scale were conducted according to data from the assessments of the teachers of 600 children. In Table 1 are the demographic characteristics of the children and their parents consisting the sample group.

Table 1. Demographic Characteristics of the Sample Group

\begin{tabular}{|c|c|c|c|c|}
\hline Scale & Variables & & $\mathbf{N}$ & $\%$ \\
\hline \multirow{14}{*}{$\begin{array}{l}\text { Emotion Regulation Che- } \\
\text { cklist }\end{array}$} & \multirow[t]{2}{*}{ Gender } & Girl & 288 & 48.00 \\
\hline & & Boy & 312 & 52.00 \\
\hline & \multirow[t]{2}{*}{ Age } & 4 age & 232 & 38.7 \\
\hline & & 5 age & 368 & 61.3 \\
\hline & \multirow{5}{*}{$\begin{array}{l}\text { Education Level } \\
\text { of Mother }\end{array}$} & Primary education & 147 & 24.5 \\
\hline & & Secondary educa- & 193 & 32.17 \\
\hline & & tion & 232 & 38.66 \\
\hline & & University & 28 & 4.67 \\
\hline & & Master / PhD & & \\
\hline & \multirow{5}{*}{$\begin{array}{l}\text { Education Level } \\
\text { of Father }\end{array}$} & Primary education & 80 & 13.33 \\
\hline & & Secondary educa- & 247 & 41.17 \\
\hline & & tion & 243 & 40.50 \\
\hline & & University & 30 & 5.00 \\
\hline & & Master / PhD & & \\
\hline
\end{tabular}

\section{Instruments}

Emotion Regulation Checklist. Emotion Regulation Checklist was developed by Shields \& Cicchetti (1995) to assess the children's emotion regulation at the age of 5-12. Emotion Regulation Checklist administered to teachers, school counselors, and parents to children's emotion regulation. The Checklist consists of 24 items and items are scored on a 4point Likert scale (1=Never; 2=Sometimes; 3=Often; 4=Almost always). The scale included two subscales, (i) Lability/Negativity and (ii) Emotion Regulation. The ERC emotion regulation subscale captures processes central to adaptive regulation, including socially appropriate emotional displays and empathy. The lability-negativity subscale assesses arousal, reactivity, anger dysregulation, and mood lability. To evaluate the factor structure of the ERC, we conducted a principal-components factor analysis using the current sample $(\mathrm{n}=322)$. We first analyzed Time 1 data and replicated using Time 2 data (1-year follow-up data). This analysis yielded two separate factors of emotion regulation (with factor loadings ranging .42 .84 at Time 1 and .47 .85 at Time 2) and emotion lability/negativity (with factor loadings ranging 
$.29 \sim .86$ at Time 1 and .35 .86 at Time 2). The two factors were correlated at -.47 at both times. One item is not included in either subscale, as it has not loaded on either scale (Shields \& Cicchetti, 1998; Kim-Spoon, Cicchetti, Rogosch, 2013). TheLability/Negativity subscale contains 15 items (Cronbach's alpha=.96) that refer to the child's tendency to become distressed; while the Regulation subscale contains eight items (Cronbach's alpha=.83) that assesses the appropriateness of the child's emotional displays (Shields \& Cicchetti, 1997). The aggregation of these two subscales produces an emotion regulation composite score that captures both regulation and dysregulation of the emotions. The composite ERC score has been found to have an internal consistency of .89 by the developers of the scale (KimSpoon, Cicchetti, Rogosch, 2013; Shields \& Cicchetti, 1998)

Pre-School Social Competence and Behavior Evaluation Inventory-Teacher Form. The Social Competence and Behavior Evaluation Inventory - Teacher Formwas developed by LaFreniere \& Dumas, 1996). Observational data was supplemented with teacher ratings of affective expression, social competence and adjustment difficulties using SCBE. Children were assessed according to 5 of the basic scales of the SCBE: depressive, anxious, angry, isolated, and oppositional. Interrater reliability for the scales calculated using Spearman- Brown estimates are uniformly high, ranging from .72 to .89. Internal consistency of the scales as assessed with Chronbach's alpha is also uniformly high, ranging from .79 to .9 1. (Walter \&LaFreniere , 2000). The scale adopted to Turkey by researchers for $4-5$ age children. This scale was completed by teachers for 617 children. The data obtained from the teachers were divided into two groups and Exploratory Factor Analysis (EFA), Confirmatory Factor Analysis (CFA) was conducted. Exploratory factor analysis (EFA) identified five factor accounting for $57.90 \%$ of the variance for Social Competence and Behavior Evaluation InventoryTeacher Form. The confirmatory factor analyses results indicated that the factor structure was partially consistent with the model. Cronbach Alpha internal consistency coefficients were .77 for general scale, were . .92, .82, .73, .72 and .74 for subscales. Spearman- Brown coefficients were . 88, .77, .70., .70 and .64 for subscales (Dereli- İman, Danişman, Yaya \& Akın Demircan, 2014).

\section{Procedure}

Turkish adaptation of Emotion Regulation Checklist was obtained through translateretranslate study. So the checklist was translated into Turkish by the researchers. Same checklist was translated into Turkish by three English specialists. The conformity of the translation 
of the researchers was compared with the other three translations. Three different specialists of the English specialists who translated the checklist into Turkish re-translated the Turkish versions of the checklist into English. The translations were reviewed by the researchers, and no meaning shift was detected. Thus, Turkish form of the checklist was ready to apply. The checklist was then presented to seven specialists who had doctorate degree in the field of preschool education and child development education, and they were revised again based on the specialists' opinions. Teachers and parents of 50 children were asked to assess their children through the checklist in order to assess the understandability of them by teachers and parents, and then a pilot scheme was conducted.

\section{Data Analysis}

Examining the Psychomectric Properties of the Emotional Regulation Checklist among 4-5 year age preschool Children, firstly checklist was determined abroad, and then confirmatory factor analysis was conducted in accordance with the items and the sub-factors. However, it was detected that the confirmatory factor analysis did not confirm for 4-5 year age preschool children in Turkey. Therefore, data from teachers were randomly cathegorized into two groups, and then Exploratory Factor Analysis (EFA) and Confirmatory Factor Analysis (CFA) were done. The exploratory factor analysis was done with the 309 data and the confirmatory factor analysis was done with the 291 data (Fraenkel \& Wallen, 1993; Şencan, 2005; Şimşek, 2007). Reliability of the checklist was tested Pearson Moment Correlation Coefficient, Spearman's Rank Correlation Coefficient, and Cronbach Alpha Coefficient. The correlation between the sub-factors of the checklist, the relationship Emotion Regulation Checklist and Social Competence and Behavior Evaluation Inventory-Teacher Form was tested the Pearson moment correlation coefficient analysis. Data were analysed the SPSS 21.0 and LISREL 8.51 package programmes.

\section{Results}

Study of Construct Validity

\section{Exploratory Factor Analysis}

After the data cleaning procedure, the two-factor structure of the scale was tested through confirmatory factor analysis to examine model fit for the scale and reveal the construct validity of the scale. The results indicate that the original two-factor model (excluding 
item 12 as mentioned before) did not fit the data. Since the examination of the model fit did not resulted appropriately, exploratory factor analysis (EFA) was used to determine if there were plausible models explaining the relationships among all of the items. Aiming a new factor structure of the scale, we firstly divided the dataset into two parts; first part was for EFA and the second part was for CFA of the emerging model. Conformity of data with the principal components analysis was examined with Kaiser-Meyer Olkin (KMO) coefficient and the Barlett Sphericity test. As a result of the analysis, KMO value was 0.95, and the Barlett Sphericity test was meaningful $(\chi 2=12273.04 ; \mathrm{p}<0.01)$. Thus, it can be said that data from the Checklist were suitable to tested exploratory factor analysis on. Factor analysis and Varimax rotation method based on Principal Components Analysis were used to reveal the factoral structures of the Checklist' items. In this study, all the communalities for the factor analysis satisfied the minimum quirement of being larger than .40 and which had a difference more than 0.10 between the loads in two separate factors (Bryman \&Cramer, 1997; Büyüköztürk, 2002; Kline, 2005)

Table 2. Structure Design of Emotion Regulation Checklist

\begin{tabular}{|c|c|c|c|c|c|}
\hline Item & $M$ & $S D$ & $\begin{array}{l}\text { Pre-loading } \\
\text { values of } \\
\text { rotation }\end{array}$ & $\begin{array}{l}\text { Factor } \\
1\end{array}$ & $\begin{array}{l}\text { Factor } \\
2\end{array}$ \\
\hline $\begin{array}{l}\text { Exhibits wide mood swings (child's emo- } \\
\text { tional state is difficult to anticipate be- } \\
\text { cause s/he moves quickly from positive } \\
\text { to negative moods. }\end{array}$ & 1.31 & .616 & .90 & .92 & \\
\hline $\begin{array}{l}\text { Transitions well form one activity to } \\
\text { another; does not become anxious, angry, } \\
\text { distressed or overly excited when moving } \\
\text { form one activity to another. }\end{array}$ & 1.26 & .632 & .88 & .91 & \\
\hline $\begin{array}{l}\text { Can reccover quickly from episodes of } \\
\text { upset or disstess (for example, does not } \\
\text { pout or remain sullen, anxious or sad af- } \\
\text { ter distressing events. }\end{array}$ & 1.30 & .603 & .80 & .90 & \\
\hline Is easily frustrated. & 1.30 & .618 & .85 & .94 & \\
\hline $\begin{array}{l}\text { Is prone to angry outbursts/tantrums } \\
\text { easily. }\end{array}$ & 1.28 & .654 & .50 & .54 & \\
\hline Is able to delay gratification. & 1.32 & .747 & .72 & .74 & \\
\hline $\begin{array}{l}\text { Takes pleasure in the distress of other ( } \\
\text { for example, laughs when another person } \\
\text { gets hurt or punished; enjoy teasing ot- } \\
\text { hers). }\end{array}$ & 1.48 & .653 & .75 & .82 & \\
\hline $\begin{array}{l}\text { Can modulate excitement is emotionally } \\
\text { arousing situations (for example, does }\end{array}$ & 1.31 & .621 & .64 & .71 & \\
\hline
\end{tabular}




\begin{tabular}{|c|c|c|c|c|c|}
\hline Is whiny or clingy with adults. & 2.20 & 1.079 & .59 & .64 & \\
\hline $\begin{array}{l}\text { Is prone to disruptive outbursts of energy } \\
\text { and exuberance. }\end{array}$ & 1.49 & .646 & .64 & .68 & \\
\hline $\begin{array}{l}\text { Responds angrily to limit-setting by } \\
\text { adults. }\end{array}$ & 1.30 & .638 & .72 & .76 & \\
\hline $\begin{array}{l}\text { Is overly exuberant when attempting to } \\
\text { engage others play. }\end{array}$ & 1.32 & .632 & .71 & .80 & \\
\hline $\begin{array}{l}\text { Responds negatively to neutral or frien- } \\
\text { dly overtures by peers (for example, may } \\
\text { speak in an angry tone of voice or res- } \\
\text { pond fearfully) }\end{array}$ & 1.48 & .648 & .74 & .88 & \\
\hline Is impulsive. & 1.41 & .645 & .65 & .67 & \\
\hline $\begin{array}{l}\text { Displays exubarence that ohters find ins- } \\
\text { trusive or disruptive. }\end{array}$ & 1.55 & .632 & .53 & .58 & \\
\hline $\begin{array}{l}\text { Displays negative emotions when attem- } \\
\text { pting to engage others play }\end{array}$ & 1.53 & .694 & .57 & .60 & \\
\hline Is a cheerful child. & 3.90 & .637 & .66 & & .67 \\
\hline $\begin{array}{l}\text { Responds positively to neutral or friendly } \\
\text { overtures by adults. }\end{array}$ & 3.70 & .670 & .74 & & .78 \\
\hline $\begin{array}{l}\text { Responds positively to neutral or friendly } \\
\text { overtures by peers. }\end{array}$ & 3.91 & .640 & .51 & & .52 \\
\hline $\begin{array}{l}\text { Can say when s/he is feeling sad, angry or } \\
\text { mad, fearful or afraid. }\end{array}$ & 3.86 & .660 & .53 & & .56 \\
\hline Seems sad or listless. & 3.78 & .668 & .65 & & .70 \\
\hline $\begin{array}{l}\text { Displays flat affect ( expression is vacant } \\
\text { and inexpressive; child seems emotiona- } \\
\text { lly absent) }\end{array}$ & 3.99 & .687 & .86 & & .88 \\
\hline $\begin{array}{l}\text { Is empathic towards others; shows con- } \\
\text { cern when others are upset or distressed. }\end{array}$ & 3.88 & .662 & .95 & & .97 \\
\hline $\begin{array}{l}\text { Display appropriate negative emotions } \\
\text { (anger, fear, frustration, distress) in res- } \\
\text { ponse to hostile, aggressive or intrusive } \\
\text { acts by peers. }\end{array}$ & 3.95 & 677 & .53 & & .59 \\
\hline $\begin{array}{c}\text { The percentage of explained variance } \\
\text { Total percent }\end{array}$ & & & $\begin{array}{c}81.12 \\
100\end{array}$ & $\begin{array}{l}53.99 \\
53.99\end{array}$ & $\begin{array}{l}27.13 \\
27.13\end{array}$ \\
\hline
\end{tabular}

Total percent

This analysis resulted in two factors having eigenvalues greater than 1 and explaining the $81.12 \%$ of the total variance. Sixteen items loaded highly on the first factor, with loadings ranging from .54 to .94; while eight items loaded highly on the second factor, with loadings ranging from .52 to .97 . Factor loadings of .71 or higher can be regarded as 'excellent', 0.63 as 'very good', .55 as 'good', .45 as 'fair', and .32 as 'poor (Comrey and Lee 1992).The first 
factor can be named as Lability/Negativity, while the second one as Emotion Regulation in parallel with the original checklist. Our results differed from the original study in that item 12 took place in the first factor, whereas it was excluded from the subscales and included in the scale separately.

Correlations between the sub-factors of the scale were tested with Pearson moment correlation coefficient, and the scores were given in Table 3.

Table 3. Descriptive Statistic and Intercorrelations Among the Sub-Dimensions of Emotion Regulation Checklist

\begin{tabular}{lllll}
\hline Sub- Factor & $M$ & SD & Lability/Negativity & $\begin{array}{l}\text { Emotion Regu- } \\
\text { lation }\end{array}$ \\
\hline Lability/Negativity & 22.84 & 5.77 & 1 & $-.39 * *$ \\
Emotion Regulation & 30.97 & 10.16 & $-.39 * *$ & 1 \\
\hline$* * p<01$ & & &
\end{tabular}

In Table 3 are the relations between the sub-factors of Emotion Regulation Checklist. According to the findings of the analysis, negative and medium level relations were found between the sub-factor of Lability/Negativity and the sub-factors of Emotion Regulation. Those findings show that no multicollinearity was between the sub-factors of the scale.

\section{Confirmatory Factor Analysis}

Confirmatory factor analysis, another type of construct validity study of the scale, was done with least squares method. In Table 4 are the fit indices related to the confirmatory factor analysis. As seen in the table, Chi-square value $\left(\chi^{2}\right)$ and statistical meaningfulness levels were calculated as $\left[\chi^{2}=710.57, \mathrm{df}=251 ; \mathrm{p}<.001\right] . \chi^{2} / \mathrm{df}$ rate was 2.83 . According to Kline (2005) and Jöreskog and Sörbom (2001), because that rate was under 3, data set had a good fit value.

Table 4. Goodness of Fit Indices related to the CFA Model for Emotion Regulation Checklist

\begin{tabular}{lc}
\hline GFI & .93 \\
\hline AGFI & .90 \\
\hline NFI & .95 \\
\hline IFI & .97 \\
\hline CFI & .97 \\
\hline
\end{tabular}




\begin{tabular}{ll}
\hline RMSEA & .07 \\
\hline S-RMR & .06 \\
\hline Df & 251 \\
\hline$X^{2}$ & 710.57 \\
\hline$X^{2} / d f$ & 2.83 \\
\hline
\end{tabular}

CFA indicates that the two-factor model fits the data well: RMSEA $=0.07, \mathrm{NFI}=0.95$, $\mathrm{CFI}=0.97, \mathrm{GFI}=0.93, \mathrm{AGFI}=0.90, \mathrm{IFI}=0.97, \mathrm{SRMR}=0.06$. The scale model is between the range of $0 \leq \mathrm{RMSEA} \leq 0.05,0.97 \leq \mathrm{NFI} \leq 1 ; 0.97 \leq \mathrm{CFI} \leq 1 ; 0.95 \leq \mathrm{GFI} \leq 1 ; 0.90 \leq \mathrm{AGFI} \leq 1$ and $0.95 \leq \mathrm{IFI} \leq 1$ it demonstrates a perfect fit; and if it is between the range of $0.05 \leq \mathrm{RMSEA} \leq 0.1$, $0.95 \leq \mathrm{NFI} \leq 0.97 ; 0.95 \leq \mathrm{CFI} \leq 0.97 ; 0.90 \leq \mathrm{GFI} \leq 0.95 ; 0.85 \leq \mathrm{AGFI} \leq 0.90$ and $0.90 \leq \mathrm{IFI} \leq 0.95$ it demonstrates an acceptable fit (Du Toit, Du Toit, Mels ve Cheng, 2008; Kline, 2005; Şimşek, 2007). When CFA results are evaluated according to these criteria, it is shown that the model is quite good. Given these indices and standardized values, it may be concluded that the model confirms the factor structure. The root mean square error approximation (RMSEA) in the fit indices was .07 . So the scale-observed values of the scale showed that the data exhibited acceptable fit. (Du Toit et al., 2008; Kline, 2005; Schermelleh-Engel, Moosbrugger \& Müller, 2003; Şimşek, 2007). In other words, that model obtained reveals that factors were confirmed by the data. 


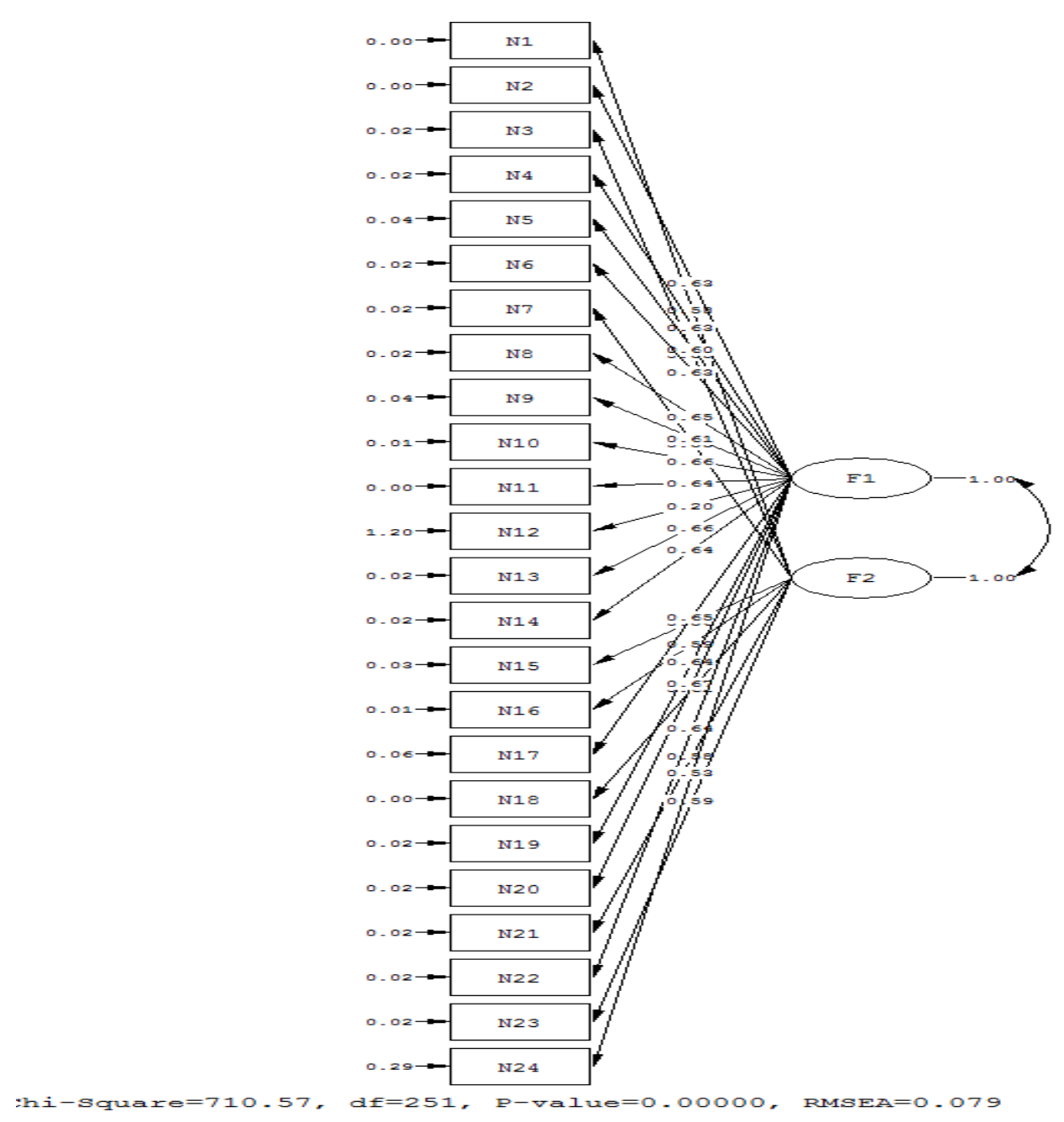

Figure 1. Results of Confirmatory Factor Analysis

\section{Criterion validity of the Emotion Regulation Checklist}

In this validity study, relation between the sub-dimensions of Emotion Regulation Checklist and the Pre-School Social Competence and Behavior Evaluation Inventory-Teacher Form was examined.

Table 5. Relationship between Emotion Regulation Checklist and Pre-School Social Competence and Behavior Evaluation Inventory-Teacher Form

\begin{tabular}{|c|c|c|c|c|c|}
\hline Sub- Factor & $\begin{array}{c}\text { Social Com- } \\
\text { petence }\end{array}$ & Anxiety & Aggression & Withdrawing & Anger \\
\hline Lability/Negativity & $-.55 * *$ & $.47 * *$ & $.37 * *$ & $.34 * *$ & $.31 *$ \\
\hline Emotion Regulation & $.41^{* *}$ & $-.47 * *$ & $-.32^{* *}$ & $-.42^{* *}$ & $-.31^{* *}$ \\
\hline \multicolumn{6}{|l|}{$* * p<.01$} \\
\hline$-547-$ & Journal of Res & $\begin{array}{l}\text { Educationa } \\
\text { org/10.1420 }\end{array}$ & $\begin{array}{l}\text { Sychology, 14(3), } \\
\text { ejrep.40.15124 }\end{array}$ & 4-556. ISSN: $1696-20$ & \\
\hline
\end{tabular}


The relation between the scores of the sub-factors of Emotion Regulation Checklist and the scores of the sub-dimensions of Pre-School Social Competence and Behavior Evaluation Inventory-Teacher Form was examined in Table 5. Positive and negative medium level meaningful relations were found.between emotion regulation checklist sub-factors and social compotence and behavior the sub-factors.

\section{Reliability of Pre-School Social Competence and Behavior Evaluation Inventory-Teacher} Form

Reliability of the scale was tested by item-total correlations, Cronbach Alpha Coefficient, Split Half Coefficient and Test-retest methods. Relation between two measurements was done three weeks apart in the test-retest reliability of the Pre-School Social Competence and Behavior Evaluation Inventory-Teacher Form for Children was examined.

Table 6. The Reliability Analysis of Pre-School Social Competence and Behavior Evaluation Inventory-Teacher Form

\begin{tabular}{lccccc}
\hline \multicolumn{1}{c}{ Sub-factor } & $\begin{array}{c}\text { Item num- } \\
\text { ber }\end{array}$ & $\begin{array}{c}\text { Item-Total } \\
\text { Correlation } \\
\text { Ranges }\end{array}$ & $\begin{array}{c}\text { Cronbach } \\
\text { Alpha Coef- } \\
\text { ficients }\end{array}$ & $\begin{array}{c}\text { Spearman- } \\
\text { Brown Co- } \\
\text { efficients }\end{array}$ & $\begin{array}{c}\text { Test-Retest } \\
\text { Correlation } \\
(n=110)\end{array}$ \\
\hline Lability/Negativity & 16 & $.42-.96$ & .98 & .93 & .83 \\
EmotionRegulation & 8 & $.75-.97$ & .98 & .88 & .91 \\
Whole Scale & 20 & - & .88 & - & .86 \\
\hline
\end{tabular}

In Table 6, Cronbach Alpha coefficients calculated for the general scale and its sub-factors range between .88 and .98 . Spearman-Brown Coefficients calculated for the sub-dimensions of the scale were between .88and .93. Test-retest correlation coefficients calculated for the general scale and its sub-factors range between .83 and .91 . Total correlation ranges of the items of the scale were .42 and .97 . 


\section{Discussion}

In the present research, validity of the Emotion Regulation Checklist for the children of the age group of 4-5 were analyzed with Exploratory Factor Analysis and the Confirmatory Factor Analysis. The two-factor structure of the scale was tested through confirmatory factor analysis to examine model fit for the scale and reveal the construct validity of the scale done (Büyüköztürk, 2002; Bryman \& Cramer, 1997; Kline, 2005).

The results indicate that the original two-factor model (excluding item 12 as mentioned before) did not fit the data. Since the examination of the model fit did not resulted appropriately, exploratory factor analysis (EFA) was used to determine if there were plausible models explaining the relationships among all of the items (Bayram, 2010; Çokluk et al., 2010). Aiming a new factor structure of the scale, we firstly divided the dataset into two parts; first part was for EFA and the second part was for CFA of the emerging model. The EFA was performed using SPSS and this analysis resulted in two factors having eigenvalues greater than 1 and explaining the $81.12 \%$ of the total variance. The first factor can be named as Lability/Negativity, while the second one as Emotion Regulation in parallel with the original scale. Our results differed from the original study in that item 12 took place in the first factor, whereas it was excluded from the subscales and included in the scale separately. Item-factor structure obtained from the first analysis has been tested by CFA. The results revealed an acceptable model fit and suggested that two factor model was confirmed with the second dataset. Items of the scale are parallel to the sub-factors they are to test in the original version of the scale. Children's emotional behaviors in a society are influenced by the expectations and the behaviors of adults. Intercultural difference between the social constructs might cause am item to take in different factor structure (Butovskaya \& Demianovitsch, 2010). Shields \& Cicchetti, (1998) found that the psychometric characteristics of the scale were similar to consist of two factors structure. Molina, Sala, Zappulla, Bonfigliuoli, Cavioni, Zanetti, Baiocco, Laghi, Pallini, De Stasio, Raccanello ve Cicchetti (2014) adapted the same scale for preschool and primary school children to İtaly. They found that similar to our study the item 12 took place in the Lability/Negativity factor and consist of two factors structure.

According to the results of analysis, negative and medium level relations were found between the sub-factor of Lability/Negativity and Emotion Regulation. Those findings show that no multicollinearity was between the sub-factors of the scale. Similarly, Shields \& Cic- 
chetti, (1998) found that negative and medium level relations were found between the subfactor of Lability/Negativity and EmotionRegulation. Molina, Sala, Zappulla, Bonfigliuoli, Cavioni, Zanetti, Baiocco, Laghi, Pallini, De Stasio, Raccanello ve Cicchetti (2014) found that negative and medium level relations were found between the sub-factor of Lability/Negativity and Emotion Regulation in Italy.

Pearson product-moment correlation coefficient has been calculated between the Emotion Regulation Checklist and Social Competence and Behavior Evaluation InventoryTeacher Form (LaFreniere \& Dumas, 1996) to test the Criterion Related Validity of the scale. Both scales were conducted on the same sample of students. Since total score cannot be obtained from the scales, the correlation coefficients has been calculated between the subscales of those scales. There was found to be statistically meaningful relationships between the subscales. According to those findings, the scale can be said to be valid. Eisenberg et.al (1993) found that children with higher emotion lability/negativity show lower levels of competent social functioning. Miller, Gouley, Seifer, Dickstein \& Shields found that children with dysregulation show more levels of anger and aggresion. Also Calkins, Gill, Johnson, and Smith ( 1999); Cole, Zahn-Waxler, Fox, Usher, and Welsh (1996), Hanish et al., ( 2004) found that children with poor emotion regulation exhibit aggressive and under controlled behaviors in social interactions, experience isolation and rejection in peer contexts, no conflicts declared.

The internal consistency was found to be .88 (Cronbach alpha reliability coefficient) for 24-item Emotion Regulation Checklist, .98 for 16-item Lability/Negativity subscale and .98 for 8-item Emotion Regulation subscale. Item-total correlation coefficients were found to be ranging between .75 and .97 for the Emotion Regulation subscale; while they ranged between .42 and .96 for the Lability/Negativity subcscale $(p<.001)$. As a result of the reliability analyses, the Emotion Regulation Checklist is a reliable assessment instrument (Büyüköztürk, 2002; Bryman \& Cramer, 1997; Kline, 2005). Shields \& Cicchetti (1998) found that Cronbach Alpha coefficient for Lability/ Negativity .89 and for Emotion Regulation .82. Molina et. al, (2014) found that the Cronbach Alpha coefficient for Lability/ Negativity .72 and for Emotion Regulation .59. 


\section{Conclusion and Suggestions}

In this research, it has been found that the Emotion Regulation Checklist are valid and reliable assessment instruments for children at the age group of 4-5. The following suggestions might be made based on that finding: Validity and reliability of Emotion Regulation Checklist can be analysed through studying with different age groups. Studies might be conducted to determine the factors that might affect emotion regulation of children. Education programmer might be developed to increase emotion regulation of children, and their efficiency might be evaluated via this assessment instruments.

\section{Appreciation}

This research is a summary of ESOGÜ BAP Project that grants directed and leader author by Assoc. Prof. Dr. Esra DERELİ İMAN and supported from Eskişehir Osmangazi University Commission of Scientific Projects (ESOGÜBAP; project code $=2013-218$ ). Also this research was presented as orally 3rd International Symposium on Economics and Social Science Conference, July 22-24, 2015, Waseda University, Tokyo, Japan.

\section{References}

Bayram, N. (2010). Yapısal eşitlik modellemesine giriş: AMOS uygulamaları [Introduction to structural equation modeling: AMOS applications]. Bursa: Ezgi Kitabevi

Berk, L.E. (2000). Child development (5th edt). Boston and London: Allyn \& Bacon.

Blair, K. A., Denhamb, S. A., Kochanoff, A., \& Whipple, B. (2004). Playing it cool: Temperament, emotion regulation, and social behavior in preschoolers. Journal of School Pyschology, 42, 419-443.

Butovskaya, M. L., \& Demianovitsch, A. N. (2002). Social competence and behavior evaluation (SCBE-30) and socialization values (SVQ): Russian children ages 3 to 6 years. Early Education and Development, 13 (2), 153-170.

Büyüköztürk, Ş. (2002). Sosyal bilimler için veri analizi el kitabı [Handbook for data analysis in social sciences]. Ankara: Pegem A Yayıncılı.

Bronson, M. B. (2000). Self- regulation in early childhood, nature and nurture. New York: The Guilford Press.

Bryman A., \& Cramer D. (1997). Quantitative data analysis with spss for windows. London: Routledge. 
Calkins, S. D., Gill, K. L.; Johnson, M. C., \& Smith, C. L. (1999). Emotional reactivity and emotional regulation strategies as predictors of social behavior with peers during toddlerhood. Social Development, 8(3), 310-334.

Carlson, S. M., \& Wang, T. S. (2007). Inhibitory control and emotion regulation in preschool children. Cognitive Development, 22, 489-510.

Cicchetti, D., Ackerman, B., \& Izard, C. (1995). Emotions and emotion regulation in developmental psychopathology. Development and Psychopathology, 7, 1-10.

Cole, P. M., Zahn-Waxler, C., Fox, N. A., Usher, B. A., \& Welsh, J. D. (1996). Individual differences in emotion regulation and behavior problems in preschool children. Journal of Abnormal Psychology, 105, 518-529.

Colwell, M. J., \& Hart, S. (2006). Emotion framing: Does it relate to children's emotion knowledge and social behavior. Early Child Development and Care, 176 (6), 591-603.

Comrey, A. L., \& Lee, H. B. (1992). A first course in factor analysis. NJ: Erlbaum.

Çokluk, Ö., Şekercioğlu, G.,\& Büyüköztürk, Ş. (2010). Sosyal bilimler için çok değişkenli istatistik SPSS ve LISREL uygulamaları [Multivariate statistics with SPSS and LISREL applications for the social sciences]. Ankara: Pegem Akademi Yayınları.

Davies, D.(2004). Child development: A practitioners guide. New York: Guilford Press.

Dereli İman, E., Danişman, Ş., Yaya, D., \& Akın Demircan, Z. (2014, Eylül). Okul öncesi sosyal yetkinlik ve davranış değerlendirme öğretmen ve ebeveyn ölçeklerinin 4-5 yaş grubu için Türkiye uyarlaması [Turkish adaptation of pre-school teachers' and parents' scales of social competence and behavioral evaluation for the age group of 4-5] 23. Ulusal Eğitim Bilimleri Kurultayı (pp.76). Kocaeli: Kocaeli Üniversitesi.

Denham, S.A.(2007). Dealing with feelings: how children negotiate the worlds of emotions and social relationships. Cognition, Brain, Behavior, 9 (1), 1-48.

Denham, S.A.( 1998). Emotional development in young children. New York, Guilford Press.

Du Toit, S., Du Toit, M., Mels, G., \& Cheng, Y. (2008). LISREL for windows simples syntax files. Scientific Software International.

Dunn, J., \& Brown, J. (1993). Early conversations about causality: content, pragmatics, and developmental change. British Journal of Developmental Psychology, 11, 107-123.

Dunsmore, J.C; Booker, J.A., \& Ollendick, T. H. (2011). Parental emotion coaching and child emotion regulation as protective factors for children with oppositional defiant disorder. Social Development, 22 (3), 1-23. 
Eggum, N. D., Eisenberg, N., Kao, K., Spinrad,T.L., Bolnick,R., Hofer, C., Kupfer, A.S., \& Fabricius, W.V. (2011). Emotion understanding, theory of mind, and prosocial orientation: Relations over time in early childhood. The Journal of Positive Psychology, 6 (1), 4-16.

Eisenberg, N., Fabes, R.A., Murphy, B., Maszk, P., Smith, M., \& Karbon, M. (1995). The role of emotionality and regulation in children's social functioning: a longitudinal study. Child Development, 66, 1360-1384.

Fraenkel, J. R., \& Wallen, N. E. (1993). How to design and evaluate research in education. New York: Mcgraw-Hill.

Gamer, P. W., Jones, D. C., \& Miner, J. L. (1994). Social competence among low-income preschoolers: Emotion socialization practices and social cognitive correlates. Child Development, 65, 622-637.

Garner, P.W. (2010). Emotional competence and its influences on teaching and learning. Education Pyschology Review, 22, 297-321.

Gross, J. J. (1998). The emerging field of emotion regulation: An integrative review. Review of General Psychology, 2, 271-299.

Gross , J.J. (2013). Emotion regulation: Taking stock and moving forward. Emotion, 13(3), $359-365$.

Hanish, L.D., Eisenberg, N., Fabes, R.A., Spinrad, T.L., Ryan, P., \& Schmidt, S. (2004). The expression and regulation of negative emotions: Risk factors for young children's peer victimization. Development and Psychopathology, 16, 334-353.

Howse, R.B., Calkins, S. D., Anastopoulos, A. D., Keane, S. P., \& Shelton, T.L. (2003). Regulatory contributors to children's kindergarten achievement. Early Education and Development, 14, 101-119.

Hyson, M. (2004). The emotional development of young children: Building an emotioncentered curriculum. New York. Teachers College Press.

Jöreskog, K., \& Sörbom, D. (2001). LISREL 8.51. Mooresvile, Scientific Software.

Kim, J., \& Deater-Deckard, K. (2011) Dynamic changes in anger, externalizing and internalizing problems: Attention and regulation. Journal of Child Psychology and Psychiatry, $52(2), 156-166$.

Kim-Spoon, J., Cicchetti, D., Rogosch, F. A. (2013). A longitudinal study of emotion regulation, emotion lability-negativity, and internalizing symptomatology in maltreated and nonmaltreated children. Child Development, 84 (2), 512-27. 
Kline, R. B. (2005). Principles and practice of structural equation modeling. New York: Guildford Press.

LaFreniere, P. J., \& Dumas, J. E. (1996). Social competence and behavior evaluation in children aged 3- to 6-years: The short form (SCBE-30). Psychological Assessment, 8, 369377.

Luby, J. L. (2005). Depression. In C. H. Zeanah (Ed.), Handbook of infant mental health (2nd ed., pp. 382-396). New York: Guilford Press.

Miller, A.L., Fine , S.E., Gouley, K. K., Seifer, R., Dickstein, S., \& Shields, A. (2006) Showing and telling about emotions: Interrelations between facets of emotional competence and associations with classroom adjustment in Head Start preschoolers. Cognition and Emotion, 20 (8), 1170-1192.

doi: 10.1080/02699930500405691

Molina, P., Sala, M. N., Zappulla, C., Bonfigliuoli, C., Cavioni, V., Zanetti, M. A., Baiocco, R., Laghi, F., Pallini, S., De Stasio, S., Raccanello , D., \& Cicchetti, D. (2014). The Emotion Regulation Checklist - Italian translation. Validation of parent and teacher versions. European Journal of Developmental Psychology, 11 (5), 624-634.

Morris, A., Silk, J. S., Morris, M. S., Steinberg, L., Aucoin, K. J., \& Keyes, A. W. (2011). The influence of mother-child emotion regulation strategies on children's expression of anger and sadness. Developmental Psychology, 47, 213-225.

Piaget, J. (1965). The moral judgement of the child. New York: Free Press.

Raikes, H. A., \& Thompson, R. A. (2006). Family emotional climate, attachment security and young children's emotion knowledge in a high risk sample. British Journal of Developmental Psychology, 24, 89-104.

Raver, C.C., \& Knitze, J. (2002). Ready to enter: What research tells policymarkes about strategies to promote social and emotional school readiness among three-and fouryear-old children. New York: National Center for Children in Poverty.

Russell, J. A. (1990). The preschooler's understanding of the causes and consequences of emotion. Child Development, 61, 1872-1881.

Saarni, C. (2001). Cognition, contex and goals: Significant compotents in social-emotional effectiveness. Social Development, 10 (1), 125-127.

Saarni, C. (1999). The Development of emotional competence. New York: Guildford Press. 
Schermelleh-Engel, K., Moosbrugger, H., \& Müller, H. (2003). Evaluating the fit of structural equation models: tests of significance and descriptive goodness-of-fit measures. Methods of Psychological Research Online, 8 (2), 23-74.

Shackman, J. E., Fatani, S., Camras, L. A, Berkowitz, M.J., Bachorowski, J. A., \& Pollak, S. D. (2010). Emotion expression among abusive mothers is associated with their children's emotion processing and problem behaviours. Cognition and Emotion, 24 (8), 1421-1430.

Shields, A., \& Cicchetti, D. (1998). Reactive aggression among maltreated children: The contribution of attention and emotion regulation. Journal of Clinical Child Psychology, 27, 381-395.

Shields, A. M., Cicchetti, D., \& Ryan, R. M. (1994). The development of emotional and behavioral self-regulation and social competence among maltreated school-age children. Development and Psychopathology, 6, 57-75.

Shields, A., \& Cicchetti, D. (1997). Emotional regulation among school-age children: The development and validation of a new criterion Q-sort scale. Developmental Psychology, 33, 906-916.

Shields, A., Dickstein, S., Seifer, R., Giusti, L., Magee, K. D.\& Spritz, B. (2013). Emotional Competence and Early School Adjustment: A Study of Preschoolers at Risk. Early Education and Development, 12 (1), 73-96.

Shields, A. M., \& Cicchetti, D. (1995, March). The development of an emotion regulation assessment battery: Reliability and validity among at-risk grade-school children. Poster session presented at the biennial meeting of the Society for Research in Child Development, Indianapo-lis, IN.

Sobanski, E., Banaschewski, T., Asherson, P., Buitelaar, J., Chen, W., Franke, B., Holtmann, M., Krumm, B., Sergeant, J., Sonuga-Barke, E., Stringaris, A., Taylor, E., Anney, R., Ebstein, R., Gill, M., Miranda, A., Mulas, F., Oades, R. D., Roeyers, H., Rothenberger, A., Steinhausen, H. C., \& Faraone, S.V. (2010). Emotional lability in children and adolescents with attention deficit hyperactivity disorder (ADHD): Clinical correlates and familial prevalence. Journal of Child Psychology and Psychiatry, 51, 915-923.

Spinrad, T. L., Eisenberg, N., Cumberland, A., Fabes, R. A., Valiente, C., Shepard, S. A., \& Guthrie, I. K. (2006). Relation of emotion-related regulation to children's social competence: A longitudinal study. Emotion, 6, 498-510.

Şencan, H. (2005). Sosyal ve Davranışsal ölçümlerde güvenilirlik ve geçerlilik [Reliability and validity in social and behavioral measurement]. Ankara: Seçkin Yayınevi. 
Şimşek, Ö. F. (2007). Yapısal eşitlik modellemesine giriş [Introduction to structural equation modeling]. Ankara: Ekinoks.

Thompson, R. A. (1994). Emotion regulation: A theme in search of a definition. Monographs of the Society for Research in Child Development, 59 (2-3), 25-52.

Trevarthen, C., \& Aitken, K J. (2001). Infant intersubjectivity: Research, theory, and clinical applications. Journal of Child Psychology and Psychiatry, 42, 3-48.

Walter, J. L., \& LaFreniere, P. J. (2000). A naturalistic study of affective expression, social competence, and sociometric status in preschoolers. Early Education and Development, $11(1), 109-122$.

Vural, D., \& Gürşimşek, I. (2009). Okul öncesi eğitimde aile katılımlı sosyal beceri eğitimi [Family involved social skills instruction on preschool education]. E-Journal of New World Sciences Academy, 4 (3), 1110-1122. 